\title{
Perception of the Nigerian Television Authority and Channels Television Reportage of the Chibok School Girls Abduction Among Residents of South-East Nigeria
}

\author{
Rev. Fr. Hyacinth C. Orlu-Orlu, PhD
}

Senior Lecturer, Department of Linguistics and Communication Studies

University of Port-Harcourt, Choba, Rivers State, Nigeria

doi: 10.19044/esj.2017.v13n23p176 URL:http://dx.doi.org/10.19044/esj.2017.v13n23p176

\begin{abstract}
This study was conducted to find out the perception of the television audience on how the Nigerian Television Authority (NTA) and the Channels Television have so far reported the abduction of over 200 female students at Government Girls Secondary School in Chibok, Borno State of Nigeria. The survey research method was used to carry out the study while the questionnaire served as the measuring instrument. The residents of SouthEast Nigeria constituted the population of the study from where a sample of 384 was drawn using the creative research systems online sample size calculator. Multi-Stage sampling technique was used to select specific local government areas, wards and households that were studied. Findings revealed that NTA's reports on the abduction of the Chibok school girls are often in favour of government while Channels Television's reports on the abduction are often balanced. The credibility level of NTA's reports on the abduction of the Chibok school girls was rated low while that of Channels Television was highly rated. Based on the findings, it was recommended amongst others that the Nigerian Television Authority (NTA) must wake up and endeavour to properly give account of the girls' abduction. The report must be devoid of ethnic, religious or political sentiment. Doing this will fundamentally lead to believability, which will consequently raise the credibility level of the reports.
\end{abstract}

Keywords: Abduction, Chibok, Perception, Reportage, School, girls

\section{Introduction}

One malaise that has continued to ravage many nations all over the world is crisis. As a result of crisis, properties worth billions are destroyed, economies of nations are crippled and ultimately, so many of lives are 
terminated. The outbreak of crisis heralds fear and devastation amongst the inhabitants of a given location. It impedes on growth and facilitates underdevelopment.

Several countries of the world have had and are still having various dosage of one form of crisis or the other. The Liberian war, Somalian crisis, Rwanda's genocide, Sierra Leonean war, Libyan crisis, Bahrain unrest, clampdown on Yemen, and the Syrian conflict are stark reminders of the crisis-prone global world we have found ourselves. The outcomes of these conflicts have been very devastating in such individual environments (Okoro and Chukwuma, 2012, p.1).

Amongst the crisis infested nations all over the world is Nigeria. Soola, (2012, p.1) assert that;

Nigeria's socio-political and economic
landscape has been blighted by the endemic
twin evil of crime and violence of major, tragic
and alarming proportions. The widespread
frustration and deep sense of insecurity to life
and property, occasioned by this epidemic, has
become a matter of grave concern to
government, security agencies and the
Nigerian citizenry at large (Nwosu, 2003). The
situation has become most critical, consequent
upon the apparent helplessness of the law-
enforcement agencies to stem the tide of the
epidemic.

One crisis currently feasting on peace and harmony in Nigeria is the Boko Haram onslaughts. The sect (which sees western education as sin) has continued to threaten the existence of Nigeria. After the arrest and subsequent murder of its former leader, late Ustaz Muhammed Yusuf, in 2009, by the Nigeria Police, the sect became very hostile which has led to the numerous loss of lives and the destruction of properties. The sect has fundamentally destroyed the economy of some states in Northern Nigeria particularly Borno, Yobe and Adamawa States. In this regard, the International Crisis Group, (2014, p.ii) asserts that;

A series of clashes between Boko Haram
members and police escalated into an armed
insurrection in 2009 . Troops crushed the
rebellion, killing hundreds of followers and
destroying the group's principal mosque.
Yusuf was captured, handed over to the police
and shortly thereafter extrajudicially executed.
Boko Haram went underground and a year 
later launched attacks on police officers, police stations and military barracks, explicitly in revenge for the killings of Yusuf and his comrades. Its spokesman demanded prosecution of those responsible, release of their detained colleagues, restoration of the mosque and compensation for sect members killed by troops. Since 2010, the group's campaign has grown, targeting not only security forces, government officials and politicians, but also Christians, critical Muslim clerics, traditional leaders, the UN presence, bars and schools. Lately it has evolved into pure terrorism, with targeting of students attending secular state schools, health workers involved in polio vaccination campaigns and villages supporting the government.

Boko Haram's four-year-old insurgency has pitted neighbour against neighbour, cost more than 4,000 lives, displaced close to half a million, destroyed hundreds of schools and government buildings and devastated an already ravaged economy in the North East, one of Nigeria's poorest regions. It overstretches federal security services, with no end in sight, spills over to other parts of the north and risks reaching Niger and Cameroon, weak countries poorly equipped to combat a radical Islamist armed group tapping into real governance, corruption, impunity and underdevelopment grievances shared by most people in the region. Boko Haram is both a serious challenge and manifestation of more profound threats to Nigeria's security (International Crisis Group, 2014, p.i).

The Boko Haram sect has successfully carried out several attacks which have resulted in the demise of many lives, destruction of properties and the collapse of the economies of some states in the Northern region of the country. Some of the very deadly Boko Haram attacks are the August 26, 2011 bombing of the United Nation's Building in Abuja which left lots of persons dead, with several others seriously wounded, the December 25, 2011 (Christmas day) bombing of St. Theresa's Catholic Church, Madalla, in Suleja Local Government Area of Niger State which also left many people dead and several others injured, the February 8, 2012, suicide bombing at the army barracks in Kaduna, September 29, 2013 attack at the College of Agriculture in Gujba which left many male students dead and the May 20, 2014 Twin bomb explosions in Jos, Plateau State which amongst many others killed were some medical students of the University of Jos. 
As earlier stated, the Boko Haram sect has successfully launched several devastating attacks in Nigeria. One of such attacks that have continued to generate global interest is the abduction of over 200 female students at the Government Girls Secondary School in Chibok, Borno State on Monday April 14, 2014. Hassan, $(2014$, p.1) asserts that "precisely on Monday $14^{\text {th }}$ April, 2014, members of the Boko Haram sect invaded the Federal Government Girls Secondary School and abducted up to 234 female students. The girls are said to be kept in the dreaded Sambisa forest."

Since the abduction of the school girls, there have been many rescue efforts including the launch of a global campaign \#BringBackOurGirls, demanding the release of the abducted girls. However, in conflict situations, such as the Boko Haram onslaughts, the media have a cardinal duty of providing the public with relevant information. The media have a core task of properly giving good accounts of the conflicts. Media reports can essentially contribute to the ignition or resolution of any conflict whether in Nigeria or any other part of the world.

The mass media often play a key role in today's conflict. Basically, their role can take two different and opposed forms. Either the media take an active part in the conflict and have responsibility for increased violence, or stay independent and out of the conflict, thereby contributing to the resolution of conflict and alleviation of violence. Which role the media takes in a given conflict, and in the phases before and after, depends on a complex set of factors, including the relationship the media have with actors in the conflict and the independence the media have with the power holders in society (International Media Support, 2006, p.4).

The mass media play huge roles in public perception, acceptance or rejection of criminal behaviour the world over. Hence the media could influence public acceptance of some ordinarily illegal steps taken by government in combating the activities of Boko Haram by the way they frame and present them. Similarly, the way the media frame and shape the Boko Haram insurrection in the people's mind can shape and condition the way the public view and responds to the sect's attacks. The mass media in Nigeria, despite coming under attacks by the Boko Haram sect can help immeasurably in building positive and courageous attitudes in the people in response to the sect's threats. This can be done through the way the media frame their reports on Boko Haram attacks. In this respect, choices of words, pictures and the language of the reports become pivotal (Ekwueme and Obayi, 2012, p.5-6).

\section{Statement of the research problem}

On Monday April 14, 2014, over 200 female students were abducted at the Government Girls Secondary School in Chibok, Borno State. In fact, 
on May 5, 2014, Leadership newspaper, on the front page, specifically reported that 234 female students were abducted at the school. Sequel to this abduction, a lot of activities such as consultations by the government, protests by the Bring Back Our Girls campaign team and even military offensives have taken place. On the part of the sect, they have continued to claim that the girls had been converted to Moslems and married off. Lately, they demanded to swap the girls with their fighters arrested by the government as well as many other developments regarding the abduction.

This abduction has so far captured the attention of several local and international media including the Nigerian Television Authority and the Channels Television. Just like other media, both Nigerian Television Authority and Channels Television had continued to serve the audience (including residents of South-East Nigeria) with various developments regarding the abduction.

The critical question here is, having watched the various Nigerian Television Authority and Channels Television reports on the Chibok school girls' abduction, and three years after such abduction, what are the views of the residents of South-East Nigeria on the manner these Nigerian television stations (Nigerian Television Authority and Channels Television) have so far reported the abduction?

Consequent upon the above, the study employed both the quantitative and the qualitative approaches to ascertain the opinions of South-East residents on how the Nigerian Television Authority and Channels Television have so far reported the Boko Haram's abduction of the Chibok school girls.

\section{Objectives of the study}

The broad objective of the study was to find out the perception of the audience on how the Nigerian Television Authority and Channels Television have so far reported the abduction of the school girls in Chibok, Borno State. However, the following specific objectives guided the study;

1. To find out the extent to which South-East residents are exposed to Nigerian Television Authority and Channels Television reports on the abduction of the school girls in Chibok, Borno State.

2. To ascertain South-East residents' perception of the nature of sources Nigerian Television Authority and Channels Television often feature in the coverage of the Chibok school girls' abduction.

3. To find out which between the Nigerian Television Authority and Channels Television often highlights peace initiatives in their coverage of the Chibok school girls' abduction.

4. To ascertain the views of the South-East residents regarding the nature of reports Nigerian Television Authority and Channels Television often transmit on the Chibok school girls' abduction. 
5. To determine the level of credibility South-East residents attach to Nigerian Television Authority and Channels Television's reports on the Chibok school girls' abduction.

\section{Research questions}

In line with the objectives of the study, the researcher advanced the following questions;

1. To what extent are the residents of South-East exposed to Nigerian Television Authority and Channels Television reports on the Chibok school girls' abduction in Borno State of Nigeria?

2. What is the perception of South-East residents on the nature of sources Nigerian Television Authority and Channels Television often feature in reporting the abduction of the Chibok school girls?

3. Which between the Nigerian Television Authority and Channels Television often highlights peace initiatives in their coverage of the Chibok school girls' abduction?

4. What are the views of South-East residents regarding the nature of reports Nigerian Television Authority and Channels Television often transmit on the abduction of the Chibok school girls?

5. What level of credibility do South-East residents attach to Nigerian Television Authority and Channels Television's reports on the Chibok school girls' abduction?

\section{Significance of the study}

1. The study shall serve as a valuable reference documnent for future researchers in this area of knowledge.

2. The Nigerian Television Authority and Channels Television shall find the study helpful as it will enable them to know how South-East residents perceive their reports on the Chibok school girls' abduction. This will help in strengthening their strategies in reporting the school girls' abduction and other related issues. In essence, the study shall serve as feedback mechanism for two television stations.

3. The intelligent community (Police, DSS, Military, etc) will equally find the outcome of this study very useful, since it will promote the need to build a common bridge between the media and intelligent communities, in the quest to bring back the abducted school girls.

4. Also, institutions of higher learning (universities, polytechnics, colleges of education, etc) shall find this study very helpful in the teaching and learning of crime and conflict reporting. 


\section{Literature review}

The mode of crime report has been the concern of media scholars over the ages. Perspectives on media's role and treatment of crime reportage vary along the various ethical divides-teleological, deontological, absolutist or relativist alike. In Nigeria, the mass media are often implicated in the allegation of fueling crime wave through glamourizing or failing to step beyond objective / neutral narrative of the notional 5Ws and $\mathrm{H}$ of crime reports (Dunlami and Busayo, 2013, p.95).

In line with the above assertion, Adisa and Abdulhareem, (2012, p.9) averred that over a long period of times, conventional coverage of conflicts in Nigeria and across the world is constantly and consistently stained with sensational stories that escalate conflicts and promote war. The media often resort to the following un-ideal ways in reporting conflicts:

1. Media mostly just follow events. They don't explain what led to those events.

2. They concentrate on bad news of conflict and are silent on peace process.

3. They are often sensational and emotional in tone.

4. Who are the news makers? They tend to focus on powerful people, political leaders, the rich and the famous who live in town and cities.

5. They often reinforce stereotypes.

6. When telling every story, they not only choose who and what to include inside the frame, but who and what to leave out.

After an analysis of media coverage of diversity and conflict issues by various scholars, Pate (2011) listed out common practices adopted by the media which tend to contribute negatively to crises situations as follows selective reporting of prejudicial stereotypes about groups and individuals, reporting inter group conflicts out of their fundamental sociological, economic, political and other contexts, shallow and episodic coverage, total blackout on some groups, individuals or community, use of inflammatory, misleading and sensational headlines to attract sales, publishing inflammatory statements against some people or groups as letters to the editor, attributing statements by individuals to groups making generalized statements not supported with facts etc. These are activities which the media need to desist from to make meaningful impact in combating insecurity in Nigeria, otherwise they (mass media) will continue to be seen as fueling insecurity (Nwabueze and Ebeze, 2013, p.867).

Even with the media publicity acclaimed to be the 'the oxygen' of terrorism, the Boko Haram sect has not hidden its disdain and distrust of the Nigerian media. Shortly after its September 28, 2011 threat to deal with the media reporters, the sect, in a display of its maniacal fury, pumped bullets into Isah Zakari, a reporter with Nigerian Television Authority and Bernard 
Akogwu, a photographer with Channels television. The condemnation that greeted the killings had hardly died down when it bombed the offices of Thisday, The Moment and Daily Sun newspapers in Abuja and Kaduna on April 26, 2012. The sect cited reasons ranging from lack of objectivity to blasphemy on the side of the media for the attacks (Ekwueme and Obayi, 2012, p.5). In this regard, the Boko Haram spokesman, Abu Qaqa stated thus: "we have just started this new campaign against the media and we will not stop here, we will hit the media hard since they have refused to listen to our plea for them to be fair in their reportage" (Ekwueme and Obayi, 2012, p.5).

A number of studies have been conducted in the area of media coverage of the Boko Haram attacks. Chukwuma did a study in 2012 on "Audience Assessment of AIT and NTA Reportage of the Boko Haram Crisis." The survey research method was used while both the questionnaire and interviewed guide were utilized as instruments for data collection. Residents of selected local government areas in Kaduna, Kano and Niger States were studied. It was found amongst others that AIT gave better reports on the Boko Haram crisis than NTA.

In 2012, Okoro and Chukwuma, conducted a study entitled "Reporting Violent Insurgencies in Postcolonial Nigeria: An Analysis of Audience Assessment of Nigerian Broadcast Media Reportage of the Boko Haram Insurgence". The study was done to ascertain the perception of the audience on broadcast media reportage of the Boko Haram insurgency. Survey research method was employed for the study while questionnaire served as the instrument for data collection. The residents of six systematically selected cities from the six geo-political zones of Nigeria constituted the study population from where a sample of 400 was drawn using Taro Yamane formular. The study unveiled, amongst others, that so far, the broadcast media have not adequately reported the Boko Haram insurgency.

Ngwu, Efetober, Ekwe and Chukwuma, in 2012, did a study on "Rethinking Terrorism Reportage for Sustainable Development: An Analysis of Media Coverage of the Boko Haram Terrorism in Nigeria." The study took a national scope in Nigeria, with the collection of primary data from six randomly selected cities, one from each of the six geopolitical zones of the country. Using survey research method, questionnaire was employed to collect primary data for the study. Based on the statistical analysis and test of hypotheses, it was found, amongst others, that media reports on Boko Haram activities in Nigeria are glorying terrorism acts. 


\section{Theoretical framework}

The Social Responsibility and the Individual Differences theories were deployed to explain the study.

\section{Social Responsibility Theory}

The social responsibility media theory owes its origin to Hutchins Commission on Freedom of the Press, set up in the United States of America in 1947 to re-examine the concept of press freedom as enunciated in the Libertarian or Free Theory (Folarin, 2002, p.31). The emergence of this theory was an attempt to provide restraint to the excessive press freedom advocated by the libertarian theory. The idea here is to ensure the press does not abuse the freedom at their disposal (Udeze and Chukwuma, 2013, p.188).

The social responsibility theory posits that the power and near monopoly position of the media impose on them an obligation to be socially responsible in discharging their duties. The theory explains that the media owe the society a duty to responsibly discharge their functions/obligations. Obot (2004, p.104), citing McQuail (1987), while highlighting the main principles of the social responsibility theory, asserts among others, that "the media should accept and fulfill certain obligations to the society." These obligations amongst others involve providing the public with adequate, objective and balanced reports on relevant developments in the society.

In line with this study, the Nigerian Television Authority and Channels Television owe the public a duty of providing adequate, accurate and balanced reports on the abduction of the Chibok school girls. These reports must be devoid of ethnic, religious and political sentiments. This is the demand of the Hutchins commission of 1947 which states that, "every responsible press devotes itself to the service of public interest which could be done through the provision of accurate, truthful and complete accounts of the day's events to the public as a matter of binding obligation"(Ngwu, 1996, p.12).

By providing adequate, accurate and balanced reportage, both Nigerian Television Authority and Channels Television would be contributing to the successful release of the girls, which is a cardinal social responsibility to be satisfied. In this regard, Adisa and Abdulhareem, (2012, p.13) citing Howard (2003), aver that through accurate and impartial news reporting, media contributes greatly to reducing conflicts.

\section{Individual Differences Theory}

This theory emerged from expositions and laboratory experiments on behaviourism, classical conditioning, learning differences and attitude formation in the late 1950s and early 1960s (Folarin, 2002, p.66). 
The theory argues that because people vary greatly in their psychological makeup and because they have different perceptions of things, media influence differs from person to person. Baran and Davis, 2012, p.180). Citing DeFleur, (1970, p.122), Baran and Davis (2012, p.181) averred that more specifically, media messages contain particular stimulus attributes that have differential interaction with personality characteristics of members of the audience.

In line with this study, the perception of the Nigerian Television Authority and Channels Television reports on the abduction of the Chibok school girls may differ from one audience to the other based on their different psychological dispositions. Depending on the psychological framework, reports from both television stations on the girls' abduction may be perceived differently by the audience.

\section{Methodology}

The survey research method was employed to generate data for the study. The questionnaire was used as data collection instrument. The residents of the five states in South-East Nigeria constituted the population of the study. According to the 2006 National Population Census, Abia state has a total population of $2,845,380$, Anambra has a total population of $4,177,828$, Ebonyi has a population of 2,176,947, Enugu has population strength of 3,267,837, while the population of Imo is 3,927,563. A summation revealed that South-East Nigeria has a total population of $16,395,555$. To generate data, a sample size of 384 was drawn from the total population using the Creative Research Systems online sample size calculator.

\section{Data presentation, analysis and results}

Out of the 384 copies of questionnaire administered, 6 were not returned while 379 copies were returned. The researchers therefore used the returned 379 copies for the analysis.

Research Question One: To what extent are the residents of South-East Nigeria exposed to the Nigerian Television Authority and Channels Television reports on the Chibok school girls' abduction in Borno State of Nigeria?

Data collected and presented on table 1 below provided answer to this research question. 
Table 1: The extent to which South-East residents exposed themselves to Nigerian Television Authority and Channels Television reports on the Chibok school girls abduction

\begin{tabular}{|c|c|c|}
\hline $\begin{array}{c}\text { Table 1a } \\
\begin{array}{c}\text { To what extent do you watch the Nigerian } \\
\text { Television Authority's reports on the abduction of } \\
\text { the Chibok school girls? }\end{array}\end{array}$ & Frequency & Percentage \\
\hline Large extent & 371 & $97.89 \%$ \\
\hline Moderate extent & 8 & $2.11 \%$ \\
\hline little extent & 0 & $0 \%$ \\
\hline Do not watch at all & 0 & $0 \%$ \\
\hline Not sure of the extent & 0 & $0 \%$ \\
\hline Total & 379 & $100 \%$ \\
\hline Table 1b & Frequency & Percentage \\
\hline $\begin{array}{c}\text { To what extent do you watch Channels Television's } \\
\text { reports on the abduction of the Chibok school girls? }\end{array}$ & 377 & $99.47 \%$ \\
\hline Large extent & 2 & $0.53 \%$ \\
\hline Moderate extent & 0 & $0 \%$ \\
\hline Little extent & 0 & $0 \%$ \\
\hline Do not watch at all & 0 & $0 \%$ \\
\hline Not sure of the extent & 379 & $100 \%$ \\
\hline Total & & \\
\hline
\end{tabular}

Table $1 \mathrm{a}$ and $\mathrm{b}$ above shows the responses of respondents on the extent to which they exposed themselves to NTA and Channels Television's reports on the abduction of the Chibok school girls. Based on data on the table, most of the respondents to a large extent exposed themselves to Nigerian Television Authority and Channels Television's reports on the abduction of the Chibok girls. This finding is in line with that of Chukwuma $(2012, \mathrm{p}, 64)$ who found in his study that the audience are to a large extent exposed to Nigerian Television Authority and Channels Television's reports on the Boko Haram crisis.

Research Question Two: What is the perception of South-East residents on the nature of sources Nigerian Television Authority and Channels Television often feature in reporting the abduction of the Chibok school girls?

The data collected and presented on table 2 below were used to provide answer to this research question. 
Table 2: Perception of South-East residents on the nature of sources Nigerian Television

Authority and Channels Television often feature in reporting the abduction of the Chibok school girls?

\begin{tabular}{|c|c|c|}
\hline Table 2a & Frequency & Percentage \\
\hline $\begin{array}{c}\text { What is the nature of sources Nigerian Television } \\
\text { Authority often feature in reporting the abduction of } \\
\text { the Chibok school girls? }\end{array}$ & & \\
\hline $\begin{array}{c}\text { Often pro-government sources } \\
\text { Often pro-Boko Haram sources }\end{array}$ & 318 & $83.91 \%$ \\
\hline Often pro-victims sources & 19 & $0 \%$ \\
\hline Sources are often balanced in their opinions & 42 & $11.08 \%$ \\
\hline Not sure of the nature of sources often featured & 0 & $100 \%$ \\
\hline Total & 379 & Percentage \\
\hline Table 2b & & \\
\hline $\begin{array}{c}\text { What is the nature of sources Channels Television } \\
\text { often feature in reporting the abduction of the } \\
\text { Chibok school girls? }\end{array}$ & Frequency & $1.58 \%$ \\
\hline Often pro-government sources & 6 & $0.26 \%$ \\
\hline Often pro-Boko Haram sources & 1 & $1.32 \%$ \\
\hline Often pro-victims sources & 5 & $96.83 \%$ \\
\hline Sources are often balanced in their opinions & 367 & $0 \%$ \\
\hline Not sure of the nature of sources often featured & 0 & $100 \%$ \\
\hline Total & 379 & \\
\hline
\end{tabular}

Table $2 \mathrm{a}$ and $\mathrm{b}$ above shows the perception of South-East residents on the nature of sources Nigerian Television Authority and Channels Television often feature in reporting the abduction of the Chibok school girls. Data collected indicate that a majority of the respondents believe the Nigerian Television Authority often feature pro-government sources in reporting the abduction of the Chibok school girls while majority of the respondents believed Channels Television often feature sources who are balanced in their opinions in reporting the abduction of the Chibok school girls. This finding is similar to that of Ovie (2005, p.18) who found in his study that government broadcast stations often featured pro-government sources in reporting the activities of the Niger Delta Militants in Nigeria.

Research Question Three: Which of between the Nigerian Television Authority and Channels Television often highlights peace initiatives in their coverage of the Chibok school girls' abduction?

The data collected and presented on table 3 were used to answer this research question. 
Table 3: The T.V. station that often highlights peace initiatives in their coverage of the Chibok school girls' abduction?

\begin{tabular}{|c|c|c|}
\hline $\begin{array}{c}\text { Which among Nigerian Television Authority and } \\
\text { Channels Television often highlights peace } \\
\text { initiatives in reporting the abduction of the Chibok } \\
\text { school girls? }\end{array}$ & Frequency & Percentage \\
\hline NTA & 84 & $22.16 \%$ \\
\hline AIT & 292 & $77.04 \%$ \\
\hline None of the two stations & 3 & $0.80 \%$ \\
\hline Not sure & 0 & $0 \%$ \\
\hline Total & 379 & $100 \%$ \\
\hline
\end{tabular}

Table 3 above shows the responses of respondents on which of Nigerian Television Authority and ChannelsTelevision often highlights peace initiatives reporting the abduction of the Chibok girls. Based on figures on the table, a majority of the respondents believe that Channels Television often highlights peace initiatives more than the Nigerian Television Authority in reporting the abduction of the Chibok school girls.

Research Question Four: What are the views of South-East residents regarding the nature of reports the Nigerian Television Authority and Channels Television often transmit on the abduction of the Chibok school girls?

The data collected and presented on table 4 below were used to answer this research question.

Table 4: The views of South-East residents regarding the nature of reports the Nigerian Television Authority and Channels Television often transmit on the abduction of the Chibok school girls

\begin{tabular}{|c|c|c|}
\hline Table 4a & Frequency & Percentage \\
\hline $\begin{array}{c}\text { What is your view regarding the nature of reports Niherian } \\
\text { Television Authority often transmit on the abduction of the } \\
\text { Chibok school girls? }\end{array}$ & & \\
\hline $\begin{array}{c}\text { Reports are often in favour of government } \\
\text { Reports are often in favour of Boko Haram }\end{array}$ & 329 & $86.81 \%$ \\
\hline Reports are often in favour of the victims & 21 & $0 \%$ \\
\hline Reports are often balanced & 29 & $7.54 \%$ \\
\hline Not sure & 0 & $0 \%$ \\
\hline Total & 379 & $100 \%$ \\
\hline Table 4b & & \\
\hline $\begin{array}{c}\text { What is your view regarding the nature of reports Channels } \\
\text { Television often transmit on the abduction of the Chibok } \\
\text { school girls? }\end{array}$ & Frequency & Percentage \\
\hline Reports are often in favour of government & 12 & \\
\hline Reports are often in favour of Boko Haram & 17 & $3.17 \%$ \\
\hline Reports are often in favour of the victims & 42 & $11.08 \%$ \\
\hline Reports are often balanced & 308 & $81.27 \%$ \\
\hline Not sure & 0 & $0 \%$ \\
\hline Total & 379 & $100 \%$ \\
\hline
\end{tabular}


Table $4 \mathrm{a}$ and $\mathrm{b}$ above show the views of the respondents on the nature of reports Nigerian Television Authority and Channels Television often transmit on the abduction of the Chibok school girls. According to data on the table, a majority of the respondents believe that NTA's reports on the abduction of the Chibok girls were often favourable to the government while another majority of the respondents view AIT's reports on the abduction of the Chibok school girls as often balanced.

Research Question Five: What level of credibility do South-East residents attach to the Nigerian Television Authority and Channels Television's reports on the Chibok school girls' abduction?

The data collected and presented on table 5 below were used to answer this research question.

Table 5: The level of credibility South-East residents attach to the Nigerian Television

Authority and Channels Television's reports on the Chibok school girls' abduction

\begin{tabular}{|c|c|c|}
\hline Table 5a & Prequency & Percentage \\
\hline $\begin{array}{c}\text { What level of credibility do you attach to the Nigerian } \\
\text { Television Authority's reports on the Chibok school girls' } \\
\text { abduction? }\end{array}$ & 8 & $2.11 \%$ \\
\hline High & 34 & $8.97 \%$ \\
\hline Moderate & 337 & $88.92 \%$ \\
\hline Low & 0 & $0 \%$ \\
\hline No credibility at all & 0 & $0 \%$ \\
\hline Can't really say & 379 & $100 \%$ \\
\hline Total & & \\
\hline Table 5b & Frequency & Percentage \\
\hline What level of credibility do you attach to Channels & 316 & $83.38 \%$ \\
\hline High & 48 & $12.66 \%$ \\
\hline Moderate & 15 & $3.96 \%$ \\
\hline Low & 0 & $0 \%$ \\
\hline No credibility at all & 0 & $0 \%$ \\
\hline Can't really say & 379 & $100 \%$ \\
\hline Total & &
\end{tabular}

Data presented on table 5a and $\mathrm{b}$ above showed respondents rating of the level of credibility they attach tothe Nigerian Television Authority's reports on the abduction of the Chibok school girls. Most of the respondents attached low level of credibility to the Nigerian Television Authority's reports on the abduction of the Chibok school girls while majority of the respondents attached high credibility to Channels Television's reports on the abduction of the Chibok school girls.

\section{Summary of findings}

Based on the analysis above, the researcher found the following; 
1. The Nigerian Television Authority often feature pro-government sources in reporting the abduction of the Chibok school girls while Channels Television often features sources that are balanced in their opinions.

2. Channels Television often highlights peace initiatives more than the Nigerian Television Authority in reporting the abduction of the Chibok school girls.

3. The Nigerian Television Authority's reports on the abduction of the Chibok girls are often in favour of government while Channels Television's reports on the abduction are often balanced.

4. The credibility level of the Nigerian Television Authority's reports on the abduction of the Chibok school girls was rated low while that of Channels Television was highly rated.

\section{Conclusion}

Based on the findings of the study, the researcher concluded that the Nigerian Television Authority has performed below expectation in reporting the abduction of the Chibok school girls while on the other hand, the Channels Television have to a commendable extent, discharged her duty to the audience. The study revealed that respondents expressed dissatisfaction with the manner the Nigerian Television Authority has so far reported the abduction. This is a revelation which the Nigerian Television Authority must accord serious attention if the station still desires to sustain the attention of the audience.

\section{Recommendations}

In line with the findings of the study, the researcher, therefore, advanced the following recommendations

1. The Nigerian Television Authority must wake up and endeavour to properly give account of the girls' abduction. The report must be devoid of ethnic, religious or political sentiment. Doing this will fundamentally raise the credibility level of the reports which will consequently herald increased patronage.

2. The federal government (owner of the Nigerian Television Authority) must restrain itself from interfering with the activities of journalists in the stations. They must allow journalists in their employ to discharge their responsibilities in line with the demands of professional journalism, particularly, in line with the tenets of conflict reporting. Ownership influence must be stopped if effective conflict reportage must be actualized.

3. Further studies in this area should go beyond the scope covered in this study by including more states that were not captured in this study for wider generalization of results. 


\section{References:}

1. Adisa, R.M. and Abdulhareem, M. (2012). Mass media and conflicts in Nigeria: A call forpeace oriented journalism. General Studies in the Social Sciences: Some Fundamentals Topics. Published by the General Studies Division, University of Ilorin, Ilorin, Nigeria. 1-16.

2. Ahmed, J.E. (2014). The media and security in Nigeria. Journal of Communication Research. 2(2). 1-17

3. Baran, S.J. and Davis, D.K. (2012). Mass communication theory: Foundations, Ferment, and Future. (6 ${ }^{\text {th }}$ edition). Wadsworth: Cengage Learning.

4. Bozzi, H.E. (2013). The mass media and the information function. Journal of Media Studies. 2(1). 1-15.

5. Chukwuma, O. (2012). Audience assessment of NTA and AIT reportage of the boko haram crisis. Unpublished Master's Thesis submitted to the Department of Mass Communication, University of Nigeria, Nsukka.

6. Ekwueme, A.C. and Obayi, P.M. (2012). Boko Haram assault on Nigeria: Towards effective Mass Media Response. Journal of New Media and Mass Communication. 5: 1-7.

7. Folarin, B. (2002). Theories of mass communication: an introductory text: Abeokuta Nigeria: Link Publications.

8. Hassan, (2014). An evaluation security situation in Nigeria. Journal of Strategic Studies. 3(1). 1-13.

9. International Crisis Group. (2014). Curbing violence in Nigeria (II): The Boko Haram Insurgency. Africa Report N²16. April 3, 2014. A Publication of the International Crisis Group, Brussels, Belgium.

10. Ngwu, C.C., Efetobor, E.O., Ekwe, O. and Chukwuma, O. (2012). Rethinking TerrorismReportage for Sustainable Development: An Analysis of Media Coverage of the Boko Haram Terrorism in Nigeria. International Journal of Research and Sustainable Development. 4(1): 166-172.

11. Nwanbueze, C. and Ebeze, E. (2013). Mass media relevance in combating insecurity in Nigeria. International Journal of Development and Sustainability. 2(2) (2013): 861870.

12. Obot, C. (2004). Mass media and conflict management. In I.E. Nwosu and D. Wilson (eds.) in Communication, Media and Conflict Management Nigeria. Enugu: Prime Targets Limited.

13. Odunlami, D. and Busayo, S.T. (2013). Culpable by indifference? An appraisal of crime reportage in Nigerian newspapers. Arabian Journal of Business and Management Review (OMAN Chapter) 2(8). 95-109. 
14. Okoro, M. N. and Chukwuma, O. (2012). reporting violent insurgencies in postcolonial Nigeria: An analysis of audience assessment of broadcast media reportage of the book haram insurgencies. Global Media Journal, V (II). 1-16.

15. Puddephatt, A. (ed.) (2006). Voices of war: Conflict and the role of the media. International Media Support (IMS).

16. Soola, E. O. (2004). Nigerian mass media coverage of crimes and violence. In Nwosu and Wilson's (eds.) Communication, media and conflict management in Nigeria. Enugu: Prime Target Ltd. 131-136.

17. Udeze, S.E. and Chukwuma, O. (2013). Broadcast Media Surveillance and National Security: An Audience Assessment. Covenant Journal of Communication. 1(2). 181195. 